Journal of Animal and Veterinary Advances 10 (14): 1785-1788, 2011

ISSN: $1680-5593$

(C) Medwell Journals, 2011

\title{
Temporal and Spatial Expression of the Pax-7 Gene During Chicken Embryo and Postnatal Development
}

\author{
${ }^{1}$ Chang Guobin, ${ }^{2}$ Liu Xiangping, ${ }^{1}$ Liao Jing, ${ }^{1}$ Chen Rong, ${ }^{1}$ Luan Deqin, ${ }^{1}$ Zhang Ying, ${ }^{2}$ Dai Aiqing, \\ ${ }^{1} \mathrm{Ma}$ Teng, ${ }^{1} \mathrm{Z}$ hou Wei, ${ }^{2}$ Wang Kehua and ${ }^{1}$ Chen Guohong \\ ${ }^{1}$ College of Animal Science and Technology, Yangzhou University, Yangzhou, 225009 Jiangsu, China \\ ${ }^{2}$ Poultry Institute, Chinese Academy of Agricultural Sciences, Yang zhou, 225003 Jiangsu, China
}

\begin{abstract}
Abstruct: This study was conducted to investigate the different temporal and spatial expression pattern of pax-7 gene in embryo stage and growth stage of chicken, aiming to explore associations between muscle development and molecular markers of pax-7 gene. Breast and leg muscle tissue were selected from $8,16,20$ and 21 days chick embryo and 2, 4, 6, 8, 10, 12 weeks rugao chickens. This study performed SYBR Green realtime fluorescence quantitative PCR to detect the expression pattern of pax-7 gene. The results showed that the expression pattern of pax-7 gene was similar between breast and leg muscles which it is lower during chicken embryo and reached to the highest point at 8-10 weeks of age. $P a x-7$ gene was continual expressed during chicken embryo and postnatal development, not only expressed in the embryo stage. Finally, we reassess current models of early patterning based on the analysis of these dynamic spatiotemporal expression patterns.
\end{abstract}

Key words: Chicken, $\operatorname{pax}-7$ gene, RT-PCR, spatiotemporal expression, tissue, China

\section{INTRODUCTION}

Growth and development of chicken muscle fiber closely related to the muscle quality traits. The particular muscle fiber type, density and diameter have significant effects on meat quality. Chicken muscle fiber number has been determined in the embryoic period, muscle fiber size increases after incubation. Pax family plays a key role on proliferation and differentiation of muscle cell in the process of muscle fibers growth and development, it is considered to candidate genes affecting characteristic of the muscle fiber. At present, function of genes affecting muscle fiber almost has not been sudied. There are pax gene family, pax-3 and 7 gene which are related to growth and development of muscle fiber (Haunerland and Spener, 2004; Walther et al., 1991; Stapleton et al., 1993). Currently, there is no data on the growth and development law of chicken pax-7 gene in different growth stages. $P a x-7$ gene expression rule in different tissues of rugao chicken were studied in this study. The aim is to explore gene expression law of pax-7 gene, reveal the developmental change the pax-7 gene expression and provide preliminary information mechanism about the candidate genes of chicken muscle fiber growth.

\section{MATERIALS AND METHODS}

Six chickens were selected from the same batch of chicken hatching $(8,16,20,21$ days after incubation) in
Yang zhou Xianglong Poultry Co., Ltd. while 2, 4, 6, 8, 10, 12 weeks rugao chicken were selected and slaughtered. Half male and half were female. Take chest, leg muscles sample and immediately frozen in liquid nitrogen, frozen samples at $-70^{\circ} \mathrm{C}$ refrigerator for use.

Primer design and synthesis: Select the $\beta$-actin gene as reference gene, primers were designed according to the chicken pax-7 gene mRNA sequence published in GenBank. Primers were synthesized by Shanghai Bioengineering Co., Ltd. The primer information and the reaction conditions are shown in Table 1.

Total RNA extraction and RT-PCR reaction: Chicken RNA was extracted using Trizol methods and the extraction step operating strictly according to kit instructions. RNA purity and concentration were detected with $1 \%$ agarose gel electrophoresis ultraviolet spectrophotometry. Chicken RNA were saved at $-70^{\circ} \mathrm{C}$ refrigerator for use. cDNA synthesis contains $10 \mu \mathrm{L}$ reaction mixture containing $5 \times$ PrimerScript buffer reaction mixture $2 \mu \mathrm{L}$, PrimerScript RT enzyme mix I $0.5 \mu \mathrm{L}$, Oligo dT $0.5 \mu \mathrm{L}$, Random 6 mers $0.5 \mu \mathrm{L}$, total RNA 500 ng, Rnase free $\mathrm{H}_{2} \mathrm{O}$ to $10 \mu \mathrm{L}$. Reaction condition was $37^{\circ} \mathrm{C} 15 \mathrm{~min}$, $85^{\circ} \mathrm{C} 5$ sec. PCR amplified DNA fragment reaction is $20 \mu \mathrm{L} .10 \times$ PCR buffer $2.0 \mu \mathrm{L}, 2.5 \mathrm{mmol} \mathrm{L}^{-1} \mathrm{dNTP} 1.5 \mu \mathrm{L}$, $10 \mu \mathrm{mol} \mathrm{L}{ }^{-1}$ primers (upstream) $1 \mu \mathrm{L}, 10 \mu \mathrm{mol} \mathrm{L}^{-1}$ primer (downstream) $1 \mu \mathrm{L}$, Taq enzyme $1.0 \mathrm{U}, 100 \mathrm{ng} \mu \mathrm{L}^{-1} \mathrm{DNA}$

Corresponding Author: Chang Guobin, College of Animal Science and Technology, Yangzhou University, Yangzhou, 225009 Jiangsu, China 
Table 1: Primers used for RQ-PCR

\begin{tabular}{llcc} 
& & & Anealing \\
Number & Sequences & Size & Temp. $\left({ }^{\circ} \mathrm{C}\right)$ \\
\hline$\beta$-actin & F: 5' GAGAAATTGTGCGTGACATCA 3' & 152 & 60 \\
& R: 5' CCTGAACCTCTCATTGCCA 3' & & \\
Pax-7 & F: 5' CTGTCACCACCTCTTTGC 3' & 142 & 60 \\
& R: 5' TGGAAGCGGGTCACATA3' & & \\
\hline
\end{tabular}

template $1 \mu \mathrm{L}, \mathrm{ddH}_{2} \mathrm{O} 13.3 \mu \mathrm{L}$. Reaction conditions are that the samples were denaturing at $95^{\circ} \mathrm{C} 15 \mathrm{~min}$, amplified by the following procedure; $95^{\circ} \mathrm{C} 20 \mathrm{~min}, 62^{\circ} \mathrm{C} 20 \mathrm{~min}, 72^{\circ} \mathrm{C}$ $20 \mathrm{sec}, 33$ cycles, $72^{\circ} \mathrm{C}$ for $7 \mathrm{~min}, 4^{\circ} \mathrm{C}$ preservation.

Constrution of standard curve: Take a certain amount of cDNA template and dilute as 10 -fold concentration. The dilute products were used to real time PCR while input concentration gradient values to quantitative PCR instrument. Based on the fluorescence response to real-time monitoring data, $\beta$-actin and pax-7 mRNA standard curve were constructed.

Quantitative PCR reaction system and reaction conditions: Reaction system $20 \mu \mathrm{L}$ contains cDNA $2 \mu \mathrm{L}$, upstream and downstream of each primer $0.8 \mu \mathrm{L}$ $\left(10 \mu \mathrm{mol} \mathrm{L}^{-1}\right)$, ROX Reference Dye $\Pi(50 \times) 0.4 \mu \mathrm{L}, \mathrm{SYBR}$ Green real-time PCR master mix $(2 \times) 10 \mu \mathrm{L}$, RNase free $\mathrm{H}_{2} \mathrm{O}$ $6 \mu \mathrm{L}$. PCR reaction conditions are $95^{\circ} \mathrm{C}, 1 \mathrm{~min} ; 95^{\circ} \mathrm{C} 15$ $\mathrm{sec} ; 60^{\circ} \mathrm{C} 34 \mathrm{sec}, 40$ cycles, analysis melting curve after amplification. PCR amplification owns unity if Tm peak is $(85 \pm 0.8)^{\circ} \mathrm{C}$ in the melting curve each real-time PCR samples were detected 3 times, take average.

Data analysis: The quantitative PCR of all RNA samples were analysised by $-\Delta \Delta \mathrm{Ct}$ method (Livak and Schmittgen, 2001). The fold changes in mRNA levels were determined as follows: $\Delta \mathrm{C}(\mathrm{T})$ non-stimulated $=\mathrm{C}(\mathrm{T})$ target gene nonstimulated - C(T) $28 \mathrm{sec}$ non-stimulated. $\Delta \mathrm{C}(\mathrm{T})$ stimulated $=\mathrm{C}(\mathrm{T})$ target gene stimulated $-\mathrm{C}(\mathrm{T}) 28 \mathrm{sec}$ stimulated. The fold change in mRNA $=2(\Delta \mathrm{C}(\mathrm{T})$ non-stimulated - $\Delta \mathrm{C}(\mathrm{T})$ stimulated).

\section{RESULTS AND DISCUSSION}

Purity and integrity of total RNA: The total RNA extracted from various tissues sampled in 1\% agarose gel electrophoresis (Fig. 1). There are 28, 18 and $5 \mathrm{sec}$ three bands and there are not significant DNA contaminated and degradated band. RNA purity were detected with UV spectrophotometer, OD260/OD280 is 1.8-1.9. It indicated that the high quality RNA extraction can be used for sub-sequent tests.

Specification of pax-7 gene primers: Figure 2 shows that the specification of pax-7 gene primers are very well.

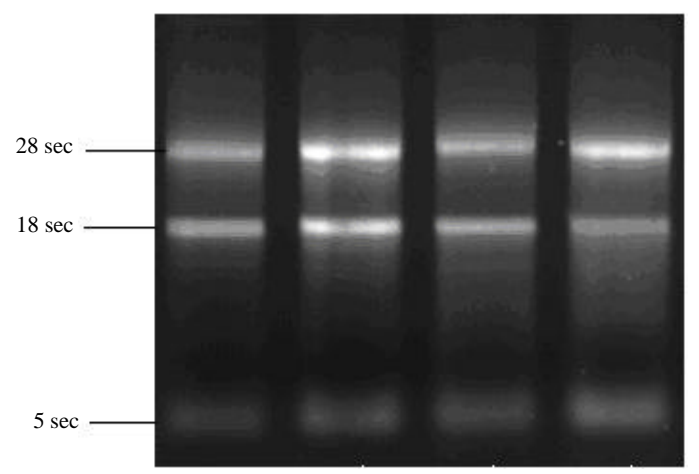

Fig. 1: 1\% agarose gel electrophoresis of extracted total RNA

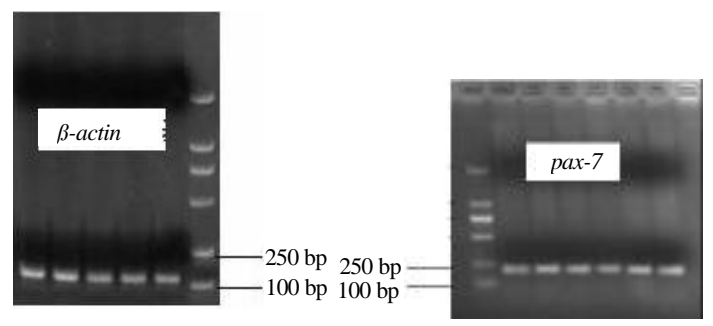

Fig. 2: Agarose electrophoresis results of PCR for RQ primers

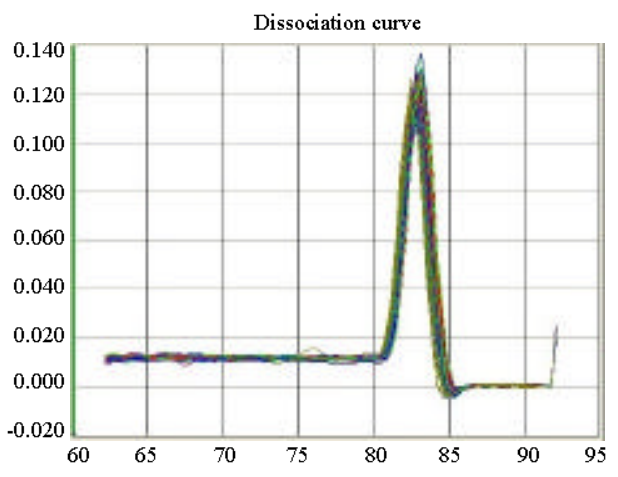

Fig. 3: RT-PCR dissociation curve for the pax-7 gene

Melting curve of fluorescence quantitative PCR: According to changes law of fluorescence after the reaction, amplification kinetics curve with cycle number and fluorescence changes detection was automatically generated, $p a x-7$ gene mRNA RT-PCR product melting curve were constructed (Fig. 3). RT-PCR gene products had only one specific peak and there were not primer dimer and non-specific product.

\section{Expression pattern of pax-7 gene}

$\mathrm{Pax}-7$ gene expression value in rugao chicken breast muscle: $P a x-7$ gene expression value in rugao chicken breast muscle in different developmental stages were showed in Table 2 and Fig. 4. Pax-7 gene expression of 
Table 2: Relative expression value of $p a x-7$ gene in breast muscle of rugao chicken

\begin{tabular}{|c|c|c|c|c|c|c|c|c|c|c|}
\hline \multirow[b]{2}{*}{ Gender } & \multicolumn{4}{|l|}{ Days } & \multicolumn{6}{|l|}{ Weeks } \\
\hline & 8 & 16 & 20 & 21 & 2 & 4 & 6 & 8 & 10 & 12 \\
\hline \multirow[t]{2}{*}{ Male } & 23.067 & 39.242 & 33.131 & 34.770 & 20.724 & 78.046 & 172.40 & 119.975 & 18.010 & 28.456 \\
\hline & \pm 0.240 & \pm 0.361 & \pm 0.236 & \pm 0.350 & \pm 0.189 & \pm 0.922 & \pm 1.320 & \pm 1.018 & \pm 0.190 & \pm 0.261 \\
\hline \multirow[t]{2}{*}{ Female } & 18.959 & 20.111 & 23.012 & 21.478 & 35.166 & 35.832 & 23.372 & 78.046 & 13.917 & 20.482 \\
\hline & \pm 0.170 & \pm 0.212 & \pm 0.218 & \pm 0.210 & \pm 0.272 & \pm 0.382 & \pm 0.214 & \pm 0.837 & \pm 0.150 & \pm 0.186 \\
\hline
\end{tabular}

Table 3: The RQ value of pax-7 gene in leg muscle of rugao chicken

\begin{tabular}{|c|c|c|c|c|c|c|c|c|c|c|}
\hline \multirow[b]{2}{*}{ Gender } & \multicolumn{4}{|l|}{ Days } & \multicolumn{6}{|l|}{ Weeks } \\
\hline & 8 & 16 & 20 & 21 & 2 & 4 & 6 & 8 & 10 & 12 \\
\hline \multirow[t]{2}{*}{ Male } & 26.73 & 32.942 & 30.244 & 37.040 & 19.770 & 64.920 & 124.842 & 118.725 & 22.907 & 18.959 \\
\hline & \pm 0.175 & \pm 0.277 & \pm 0.180 & \pm 0.201 & \pm 0.163 & \pm 0.535 & \pm 1.1130 & \pm 0.960 & \pm 0.240 & \pm 0.136 \\
\hline \multirow[t]{2}{*}{ Female } & 32.954 & 20.128 & 26.102 & 32.396 & 25.531 & 34.984 & 68.0830 & 100.45 & 32.082 & 29.254 \\
\hline & \pm 0.321 & \pm 0.129 & \pm 0.250 & \pm 0.236 & \pm 0.164 & \pm 0.377 & \pm 0.6440 & \pm 0.839 & \pm 0.243 & \pm 0.301 \\
\hline
\end{tabular}

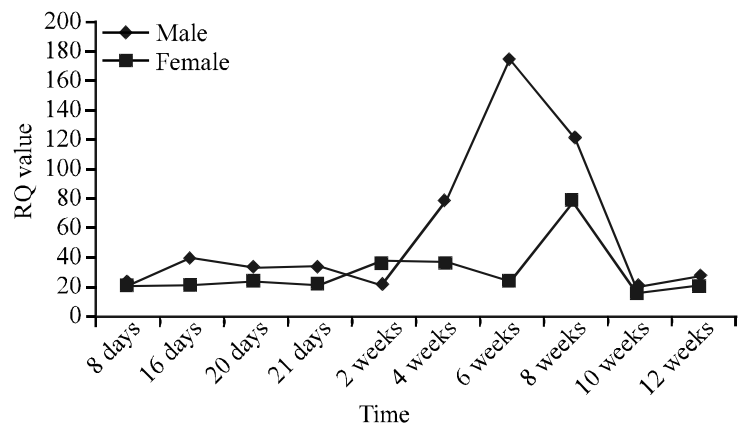

Fig. 4: $\mathrm{Pax}-7$ gene expression in different periods in breast muscle tissue

rugao chicken breast muscle showed in Fig. 4. It can be seen from Fig. 4 that gene expression of breast muscle of male chicken has been stable from incubation to born, the expression level increased rapidly after 2 weeks of age, gradually increased to the highest level of 6 weeks and began to decline at 8 weeks of age, down to low level at 10 weeks of age. The gene expression of breast muscle of female chicken keep stable from incubation to 6 weeks of age, rapidly rose to the highest poin at 8 weeks of age. $P a x-7$ gene expression was also maintained a high level then decreased rapidly and maintained the birth expression level after 10 weeks of age.

Pax-7 gene expression value in rugao chicken leg muscle: $P a x-7$ gene expression value in rugao chicken leg muscle in different developmental stages were showed in Table 3 and Fig. 5. It can be seen from Fig. 5 that gene expression of leg muscle of male chicken are the same in the embryonic period and at different growth stages and gene expression of leg muscle of female chicken increased rapidly at 2 weeks age, reached a peak at 8 weeks of age then fall, kept the birth expression level at 12 weeks age. The expression level of female chicken is less than that of male chicken.

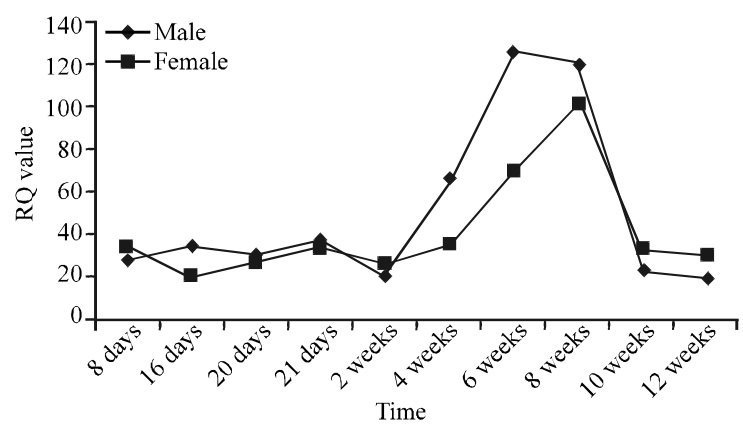

Fig. 5: $\mathrm{Pax}-7$ gene expression in different periods in leg tissue of rugao chicken

Relative quantification method: Relative quantification is used to quantification of gene expression is to calculate the relative gene expression level compared to the reference gene. Compared with the absolute quantification, the value calculated with this method is a relative value, not the copy number of gene transcription. But at the same time, this method eliminate the need for steps such as building a standard curve, the operating method is relatively simple and time-saving. Statistical results showed that the results of this method is very reliable in gene expression variation analysis. During the relative quantitative analysis, the following areas are optimized in order to ensure reliable results.

Choice of reference gene: GAPDH, $\beta$-actin, 18 sRNA are generally selected as reference gene. Taking into account in animal muscle constant expression, the gene in humans, pigs, chickens, ducks and geese and other species is conservative so, $\beta$-actin gene was chosen in this study.

The choice of primers: In this study, we have chosen the SYBR Green method, the dye can not only combine with the target sequence but also combine primer dimers and nonspecific amplification products in PCR amplification process. In the primers design process, first consider the 
intron design and reduce DNA contamination caused by non-specific amplification. To ensure the amplification efficiency between $90-110 \%$, fragment length of primers is within $300 \mathrm{bp}$ and primers were screened.

Construction of standard curve: The curve was constructed with recombinant plasmid as a template in this study. To solve different primer amplification efficiency problem, the ABI 7500 SDS V2.01 Version of the software were used to data analysis, the software can calculate the relative expression value when amplification efficiency is inconsistent.

\section{CONCLUSION}

Research has shown that pax-7 gene interacts with pax-3 in embryonic periods and control embryonic development of muscle fiber. $P a x-7$ gene is related to muscle repair and regeneration of muscle cells in animals after birth. The number of muscle fibers have been identified before birth and pax-7 can repair muscle and make muscle cell regeneration (Seale et al., 2000; Oustanina et al., 2004). Expression study of the pax-7 gene in embryonic and postnatal expression showed that pax-7 gene expression levels were the highest in embryonic periods, decreasing after birth. $P a x-7$ gene expression of female chicken peaked at 6 th week age and at 8th week age in male. It proved that pax-7 gene had the repair function of animal muscle. This need to be further explored. The inconsistent early peak times of expression may be related to different physiological states during early growth and development process.

\section{ACKNOWLEDGEMENTS}

This research was supported by National Natural Science Foundation of China (Grant No. 30972088) and Natural Science Foundation of Jiangsu province, China (Grant No. BK2009190).

\section{REFERENCES}

Haunerland, N.H. and F. Spener, 2004. Fatty acid-bindingproteins insights from genetic manipulations. Prog. Lipid Res., 43: 328-349.

Livak, K.J. and T.D. Schmittgen, 2001. Analysis of relative gene expression data using real-time quantitative PCR

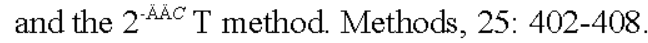

Oustanina, S., G. Hause and T. Braun, 2004. Pax 7 directs postnatal renewal and propagation of myogenic satellite cells but not their specification. EMBO J., 23: $3430-3439$.

Seale, P., L.A. Sabourin, A. Girgis-Gabardo, A. Mansouri, P. Gruss and M.A. Rudnicki, 2000. Pax 7 is required for the specification of myogenic satellite cells. Cell, 102: 777-786.

Stapleton, P., A. Weith, P. Urbanek, Z. Kozmik and M. Busslinger, 1993. Chromosomal localization of seven PAX genes and cloning of a novel family member, PAX-9. Nat. Genet., 3: 292-298.

Walther, C., J.L. Guenet, D. Simon, U. Deutsch and B. Jostes et al., 1991. Pax: A murine multigene family of paired box-containing genes. Genomics, 11: 424-434. 